\title{
The Effective Factors on Academic Motivation and Its Level in the First-Level Seminary Students in the Mashad Howzeh
}

\author{
-Mahdi Qaemi Nik ${ }^{1}$ - Ali Saeidi ${ }^{2}$
}

Objective: This study investigates the effective factors on academic motivation and its level in the first-level male students in the Mashad Howzeh (Seminary).

- Method: The methodology of the research is a descriptive survey one, and its statistical population included all the first level male students at Mashhad Howzeh, who were studying in the academic year 2019-2020, and their schools teachers and officials. Among this statistical population, 139 students from the first to the fifth grade among 5 seminary schools as the sample participated voluntarily. In addition, 12 teachers and officials of these schools were selected as the available sample. ISM Academic Achievement Motivation Questionnaire and semi-structured interviews with the teachers, principals and officials at the Mashhad Howzeh (Seminary) were used to collect data. One-sample T-Test, Friedman Ranking Test, and Analysis of Variance were used to analyze the data.

- Finding: The findings showed that $6.5 \%$ of students had low motivation, $88.5 \%$ had moderate motivation, and 5\% had high motivation. Among the components of academic motivation, the average of the tendency to work and study, tendency to progress, purposefulness, self-esteem, self-reliance, spiritual rewards and social cooperation was desirable.

Conclusion: Furthermore, the findings of the interviews with the schools officials and teachers of these students showed that the most important factors in reducing motivation are the lack of awareness of goal and the career future, the large volume of courses and, in some cases, disproportionate ones, and choosing an unmotivated and inappropriate friend. From the their teachers' point of view, presenting the courses in a practical way, developing personality in the students and giving them dignity, having an appropriate role model, and paying attention to the spiritual affairs and recourse (tawassul) are the most important factors in increasing students' motivation.

Keywords: motivation, academic motivation, Howzeh (Seminary), the seminary students in the first level

Citation: Mahdi Qaemi Nik, Ali Saeidi.(2021). The Effective Factors on Academic Motivation and Its Level in the First-Level Seminary Students in the Mashad Howzeh Applied Issues in Islamic Education, 6(3): 61-80.

Received: 2021/05/31_Accepted: 2021/08/03

1. An MA in Educational Psychology, Al-Mustafa University, Mashhad Branch, Mashhad, Iran E-mail: mirzaqaeminik1359@gmail.com (iD) 0000-0002-2251-4278

2. Corresponding Author: An Assistant Professor, the Department of Psychology and Counseling, Farhangian University, Mashhad, Iran

E-mail: ali.saeidi@cfu.ac.ir (D) 0000-0002-9112-0619 


\section{بررسى ميزان وعوامل مؤثر \\ بر انكَيزش تحصيلى بيلى طلاب \\ سطح يك \\ حوزه علميبه مشثهد}

" محمدمهدى قائمىنيك" " على سعيدى"

\section{बـمك}

ه هدف: هدف يُروهش حاضر بررسى ميزان و عوامل مؤثر بر انگيزش طلاب برادر سطح يك مه شهر مشهرد بود.

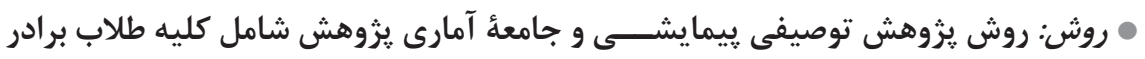

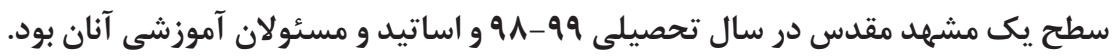

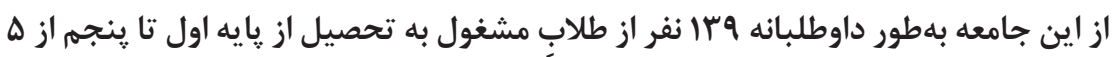

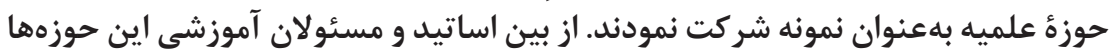

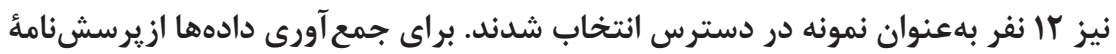

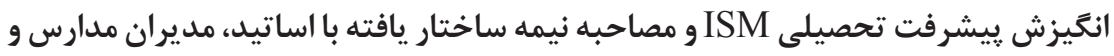

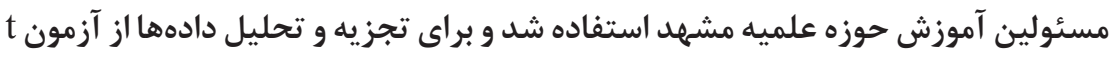

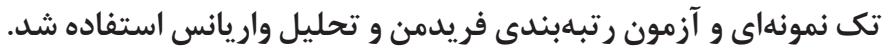

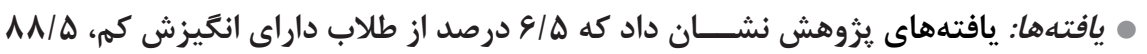

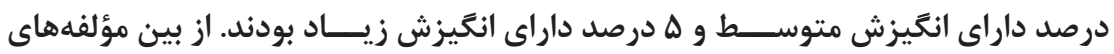

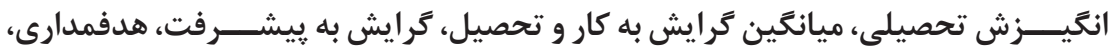

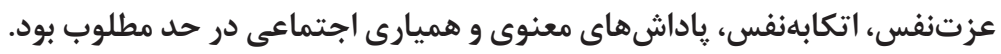

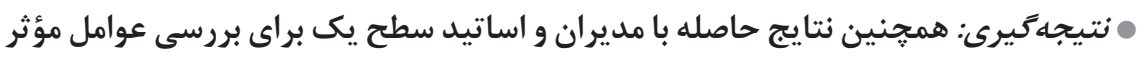

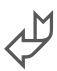


بر ايجاد و افت انكيزش تحصيلى طلاب از ديدَاه مديران و اساتيد حوزه نشان داد كه جهل

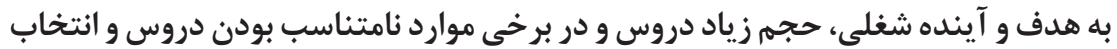

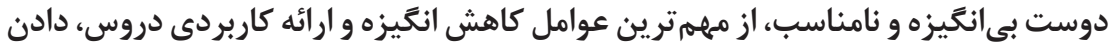

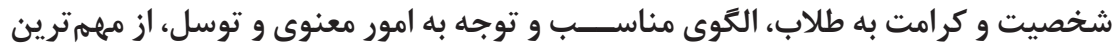
عوامل افزايش انغيزش طلاب از نظر اساتيد است.

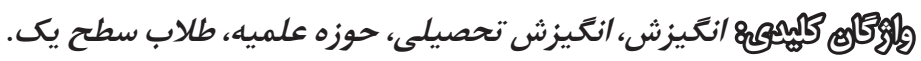

\section{مڤندم}

امروزه نظام آموزش و يرورش هر كشـــــور به دنبال شناسايى عوامل مؤثر بر فرايند

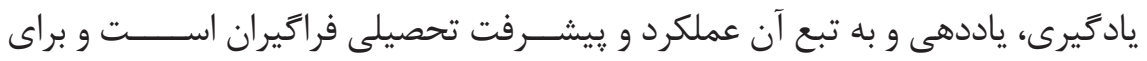
رشــــد و تعالى اهداف موردنظر و راهكارهاى رسيدن به آنها كامى بر مى عـارد. (قوامى، عابدى و نيل فروشــان وqس ا، به نقل از عســكرى، منظرى توكلــى، منظرى توكلى و زين الدينى، وجس (). يكى از عوامل بســيار مؤثر بر اين فرايند انخيزش است. انخيزش ا

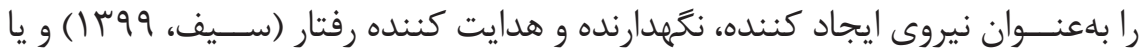
فر آيندهايى مانند نياز، شـــاخت، هيجان و رويدادهاى بيرونى كه به رفتار، نيرو و جهت مى دهند(رمضانى، و9٪|) تعريف كردهاند. مســائل اساسى كه در روانشناسى انخيزش مطرح مى شــود، عبارتاند از اينكه: جرا رفتار خاصــى يديد مى آيد؟ جرا رفتار هدفدار

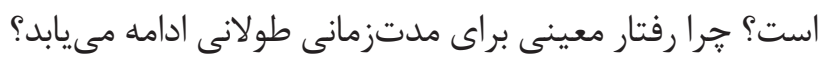

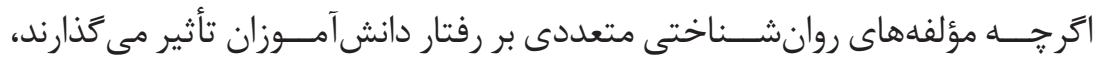
انخيزش تحصيلى ب از مهمترين عوامل روانشناختى مؤثر در ريشرفت تحصيلى در نظر كرفته مىشود (Steinmayr \& Spinath, 2009). در واقع انخيزش كليد يادگيرى است. انخيزش تحصيلى عبارت اســت از گرايشــى همهجانبه به ارزيابى عملكرد خود با توجه به عالى تريــن معيارهاى تلاش براى موفقيت در عملكرد و برخـــوردارى از لذتى كه با موفقيــت در عملكرد همراه اسـت (Westland \& Arche, 2001 ، به نقل از دليرناصر و

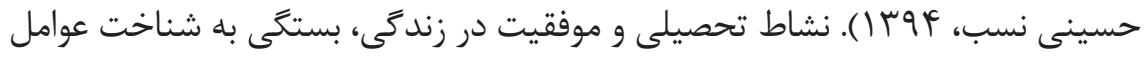




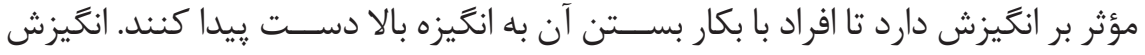
تحصيلى به رفتارهايى مربوط مىشود كه به نوعى با عملكرد و موفقيت تحصيلى مرتبط هستند، از جمله اينكه دانشآموزان جقدر تلاش مى كنند، جُگونه كار خود را بهطور مؤثر

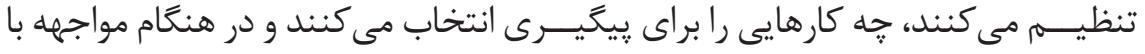
موانع جقدر يايدار هســتند (Schunk, Meece \& Pintrich, 2012). نوزادان و كودكان نو:ا بهطور طبيعى به يادگيرى و شـــاخت دنياى پيرامـــون خود علاقه دارند. با افزايش تجارب منفى در مدرســه، علاقه به يادَيرى و شــناخت برخى از دانش آموزان كاهش مىيابد زيرا اين كونه مىانديشند كه تلاش آنان تغييرى در نتيجه به وجود نخواهد آورد

.(Rowell \& Hong, 2013) مطالعــات مختلف ارتباط ميان انگگيزش تحصيلى و عملكـــرد يادگيرندگان را تأييد كردهانـــ (Clark, Middleton, Nguyen, \& Zwick, 2014; Brian, 2015). براى مثال مئل يافتههاى ايزدى، جويبارى، بهناميور و تقوى (بوس|) بر روى دانشجويان دانشخاه علوم يزشــكى گلســـتان نشـــان داد كه با افزايش انخَيزه تحصيلى، عملكرد دانشجويان نيز

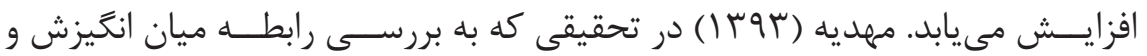
ييشرفت تحصيلى در دو گروه از طلاب ورودى سيكل و دوره متوسطه يرداخته است به اين نتيجه رسيده است كه ميان انخيزش و ريشرفت تحصيلى طلاب رابطه مثبت وجود

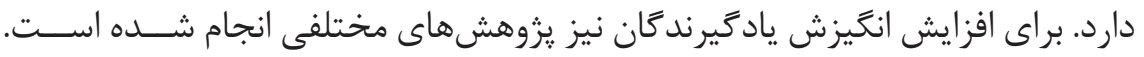
نتايج يزوهش ناصح، مراديان دهكردى و ناصح (9 (1) بر روى دانشــجويان دانشگاه علوم يزشكى شهركرد نشان داد جهت افزايش انخيزه تحصيلى دانشجويان برنامههايى همجون توانمندسازى اساتيد در كاربرد تئورىهاى مختلف انگَزشى مؤثر خواهد بود.

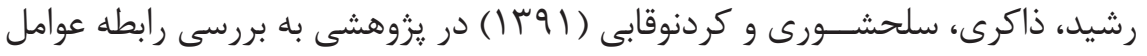
مختلــف محيطى بر انخَيزش يرداختند. نتايج يثوهش آنان نشــان داد كه بين عوامل فردى، عوامل خانوادگى (جز يايگًاه اجتماعى - اقتصادى خانواده)، عوامل آموزشگاهى و عوامل اجتماعى با انخيزه تحصيلى دانش آموزان رابطه معنى دارى وجود دارد. بنابراين

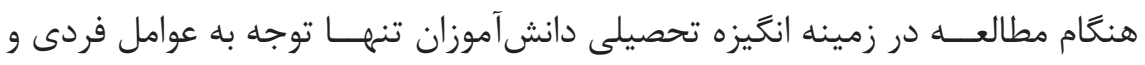
روانشناختى كافى نيست، بلكه در اين زمينه بايد به مجموعه اي از عوامل خانوادگى، 
انخيــزش، بين محققان اتفاق نظر وجود دارد كه انظيزش تحصيلى با مهارتها و نتايج مثبت تحصيلى و مرتبط با سلامت، مانند خودتنظيمى، يشتكار، تفكر انتقادى، ييشرفت

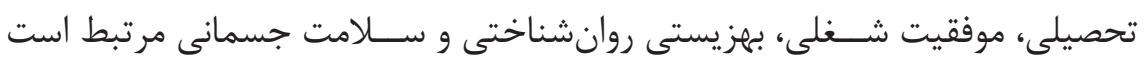

(Zaccoletti, Camacho, Correia, Aguiar, Mason, \& Daniel, 2020) حوزة علميه، محل كسب علوم و آتاهى هاى اسلامى و آشنايى با فرهنگ اسلام توأم با عمل و اخلاص و زهد، با نظامى متكى به احساس مسئوليت دينى (موحد ابطحى، هوس |) و مركز اصلى نهاد علم و آموزش در تمدن و فرهنگ ايرانى - شيعى (رحمانى، بوس |) بوده اســت. در نظام آموزشى حوزه، طلاب علوم دينى داراى :جهار سطح علمى هستند. منظور از طلاب سطح يك، دوره مقدمات شش يائُ اول تحصيلى حوزء علميه است. تقسيمبندى ديخرى نيز وجود دارد كه سه سال اول طلبگى را، كه در آن ادبيات عرب خوانده مىشود،

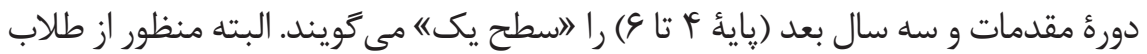
سطح يك در اين يزوهش همان معناى اول يعنى پايه اول تا ششم مىباشد. دانشيثوهان علوم دينى در اين سطح، دروسى همجون صرف و نحو و معانى بيان را مى خوانند. از ديخر

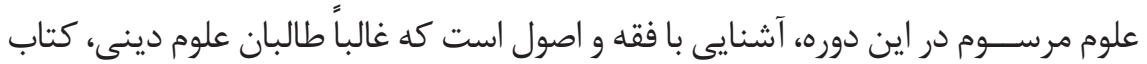
اصول فقه مرحوم مظفر و شرح لمعه مرحوم شهيد ثانى را مى خوانند.

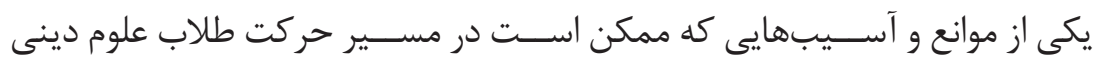
بالســمت رشــد و كمال علمى و معنوى به وجود آيد ضعف انخيزه طلبكى است. ضعف انخيزه نهتنها به خودى خود يك آسيب جدى بلشمار مىرود، بلكه ممكن است زمينهساز بروز برخى آســيبهاى اخلاقى، تربيتى و تحصيلى طلاب نيز زردد. انخيزش تحصيلى نيز نه تنها در هنگَام انتخاب زندگى طلبكَى و ورود به حوزه علميه مهمم اســت بلكه در تمام طول تحصيل سطوح حوزوى نيز مىتواند يكى از عوامل مؤثر بر موفقيت و يا عدم موفقيت طلاب باشــــ. رفتارهايى نظير مطالعه، شركت منظهم در كلاس درس، مشاركت در بحثهاى كلاسى، مباحثه، يیش مطالعه و انتخاب تكاليف جالشانخيز از شاخصهاى رفتارى انخيزش تحصيلى هستند. از راههاى گوناگونى مى توان ايجاد انخيزه كرد و علاقه طلاب حوزه را به درس و بحث افزايش داد. در مورد ميزان انخيزه يادگيرندگان يزوهش هاى مختلفى انجام گرفته اســت كه از آن جمله مى توان به مطالعه روحى و آسـايش ( (1 (1) اشاره كرد كه يافتههاى آن نشان داد 
انگَيزه تحصيلى سه درصد از دانشجويان دانشگاه علوم يزشكى گلستان بالاتر از ميانگين و

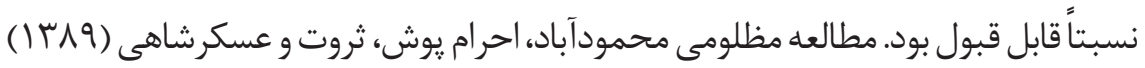
نيز حاكى از اين بود كه هـ درصد از دانشجويان شهر يزد انخَيزش تحصيلى يايين داشتند و رفتارهاى يرخطر نيز در اين دانشجويان بيشتر از دانشجويان داراى انگيزش تحصيلى بالابود. دوران آموزش در حوزه علميه بهطور سنتى، دوره اى طولانى است كه كاه تا بيست سال و بيشتر طول مى كشد (رحمانى، بوץ () به همين خاطر طلاب بايد انخيزش تحصيلى بالايى داشته باشند تا در طول زمان بتوانند به يادَيرى ادامه دهند. يزوهش هاى صورت

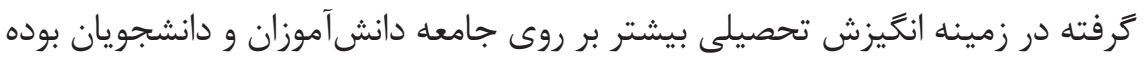
و بررســى ييشينه يزوهش نشــان داد بهجز جزند مورد مقاله كه حاكى از نظر شخصى نويسند أن آن مىباشد و مواردى نيز مصاحبه (غيرعلمى) با تعدادى طلاب، كار ميدانى (ييمايشــى) خاصى در زمينه انخَيزش تحصيلى طلاب حوزه علميه انجام نشــده است. نقش و اهميت بســـيار بالاى حوزه علميه در تعليم و تربيت اســلامى و لـــزوم اصلاح و تحول در اين نظام آموزشــى براى حفظ يويايى و بالندگى آن (شعبانى، ناطقى و فقيهى،

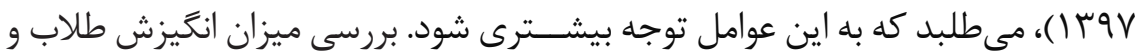
شناخت عوامل مؤثر بر آن، يك عامل اثرگذار بر ييشرفت تحصيلى طلاب بشمار مىرود.

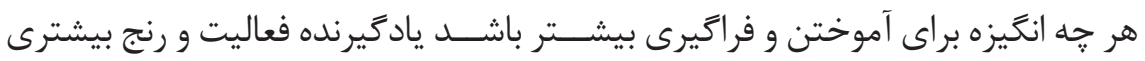
براى رسيدن به هدف متحمل خواهد شد. آتاهى دست اندر كاران حوزههاى علميه درباره ميزان انگَيزش تحصيلى طلاب و مؤلفهها و عوامل مؤثر بر آن مىتواند به ييشبرد سطح آموزشى حوزه و برنامهريزى بهتر در اين خصوص كمك كند؛ لذا يزوهش حاضر به دنبال ياسخ دادن به سؤالات زير بوده است.

ا. انخيزش تحصيلى طلاب برادر سطح يك شهر مشهد جه قدر است؟ r. مؤلفههاى انخيزش تحصيلى طلاب ســـح يك شهر مشهد در جه سطحى قرار دارند؟ r. عوامل مؤثر بر افت انخَيزش تحصيلى طلاب ســطح يك از ديدگاه اساتيد حوزه F. عوامل مؤثر بر ايجاد انگيزش تحصيلى طلاب سطح يك از ديدگاه اساتيد حوزه 
روش يزوهش حاضر توصيفى ييمايشى است. جامعه آمارى طلاب شامل تمامى طلاب برادر سطح يك مشهد است كه بعد از پايان كلاس نهمم (سوم راهنمايى) وارد حوزه شده

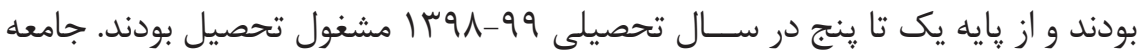
اساتيد نيز شامل تمامى اساتيدى است كه در سال تحصيلى مذكور مشغول تدريس اين

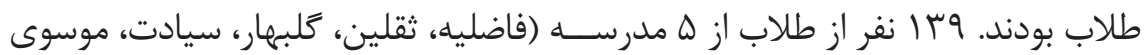
نزاد)، به صورت داوطلبانه، بهعنوان نمونه يزوهش انتخاب شدند. از بين جامعه اساتيد و

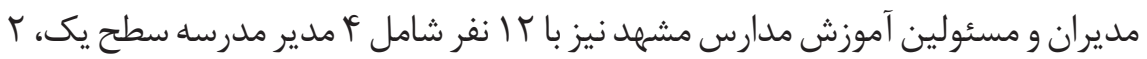
مسئول آموزش و 9 استاد كه همكَى داراى تحصيلات سطح ع حوزه (سه نفر مدرس سطح عالى و بقيه مدرس سطح يك حوزه) بودند، بهعنوان نمونه در دسترس، مصاحبه گرديد.

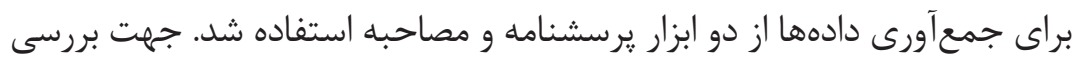

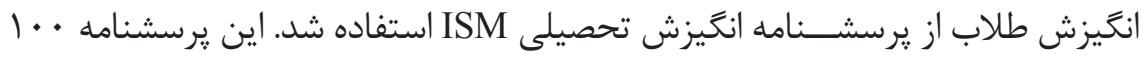
سؤالى در سال 199 أتوسط مك اينرنى (McInerney) و سينكلاير (Sinclair) طراحى كرديد. فرم كوتاه اين يرسشـــنامه توســـ بحرانى ساخته شــده و در شيراز هنجاريابى

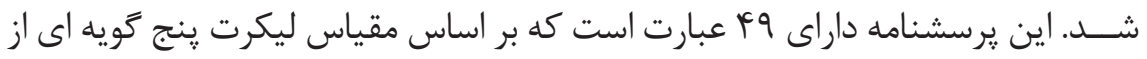

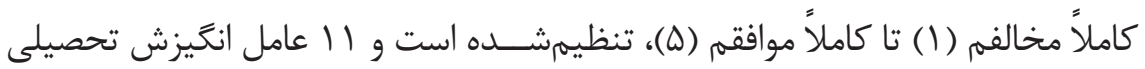
شامل گرايش به كار و تكليف، گرايش به بيشرفت، هدف مدارى، عزتنفس، اتكابهنفس، رقابتجويى، قدرتطلبى، شهرتطلبى، ياداشهاى مادى، هميارى اجتماعى و وابستگى اجتماعى را مىســنجد. روايى و يايايى اين يرسشنامه در مطالعات خارج از كشور مورد

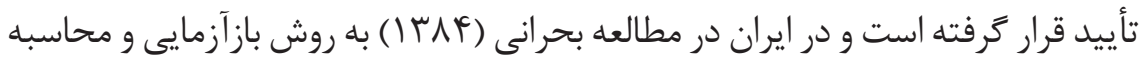
آلفاى كرونباخ اندازهزيرى شــده كه ضريب يايايى كل آزمون ه9/ • محاســبه گرديد.

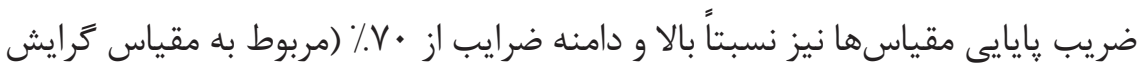

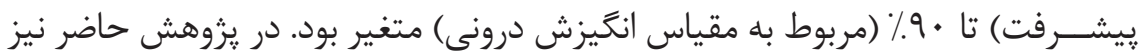
يايايى آزمون مورد ســنجش قرار گرفت و مقدار ضريب آلفاى كرونباخ محاسبه شده در

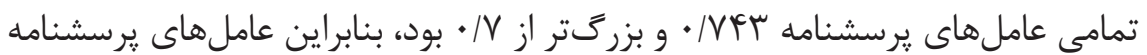

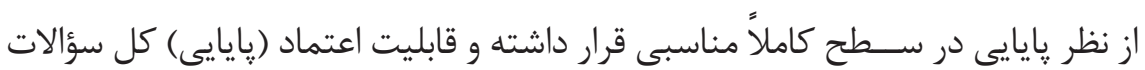
يرسشنامه مورد تاييد قرار زرفت. مقدار صفر اين ضريب نشاندهنده عدم قابليت اعتماد 


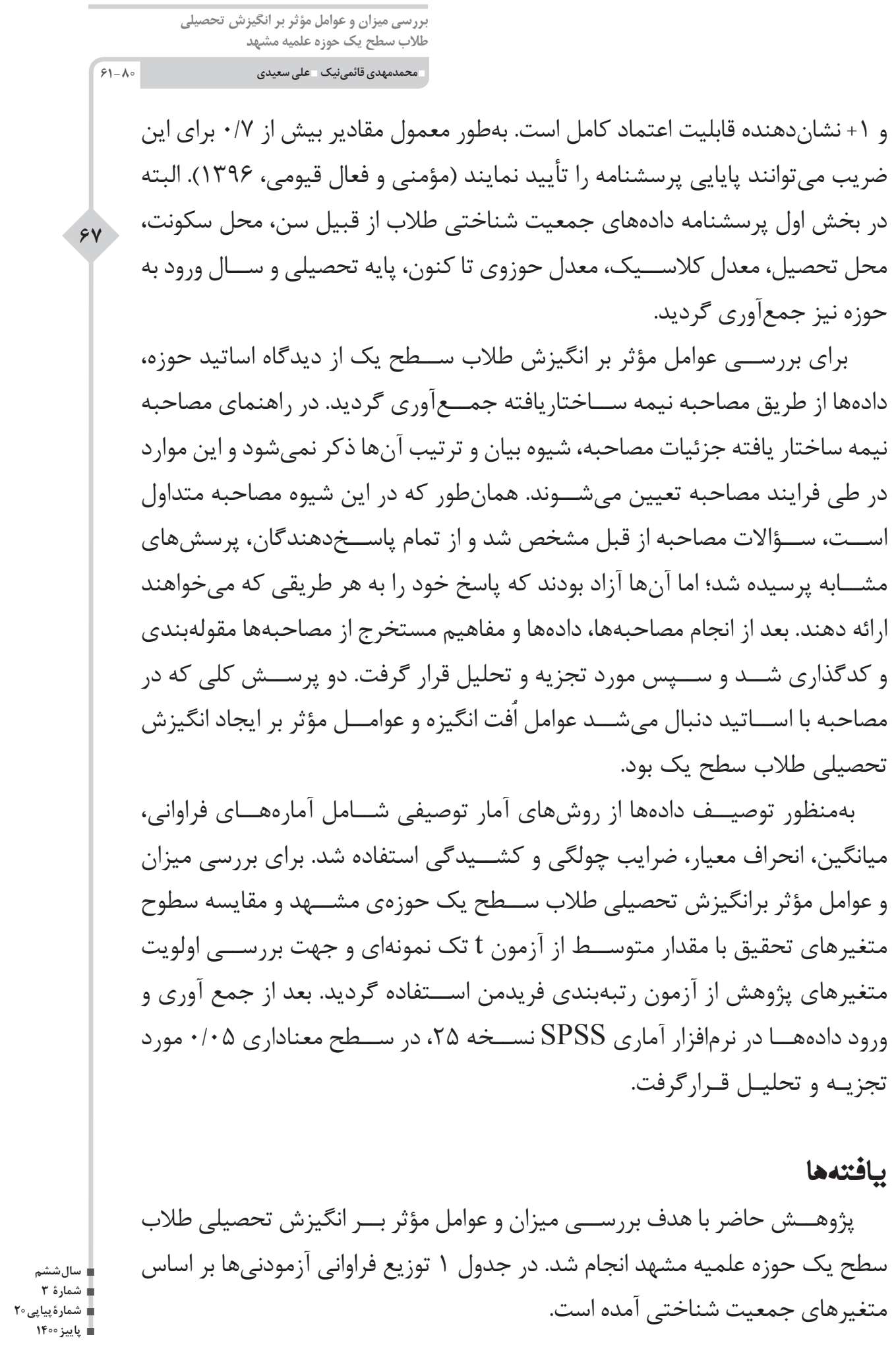


جدول ا. توزيع فراوانى آزمودنىها بر اساس متغيرهاى جمعيت شناختى

\begin{tabular}{|c|c|c|c|c|c|}
\hline انحراف معيار & ميانگين & بيشتر ين & كمقدرين & تعداد & ن متغير \\
\hline I/VAr & $M / I F D$ & ra & 10 & ira & سن \\
\hline $1 / r \cdot \Delta$ & $1 \Lambda / F r q$ & r. & If & irr & معدل كلاسيك \\
\hline $1 / r \cdot v$ & IVIATF & $19 / 91$ & If & IrT & معدل حوزوى \\
\hline
\end{tabular}

جدول ا نشان مى دهد كه دامنه تغييرات سن شركت كنندگان در يثرهش بين ها تا

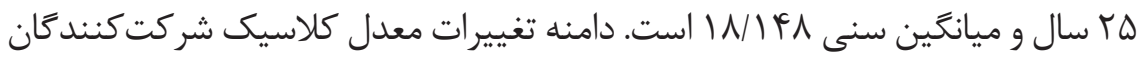

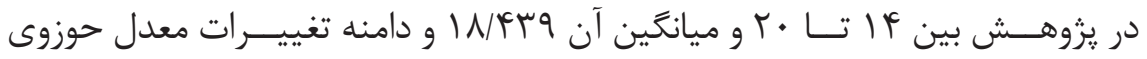
شركت كنند براى ياسخ دادن به سؤال اول يخوهش در مورد ميزان انخيزش طلاب، نمره كلى انخيزش يُش تحصيلى محاسبه گَرديد. براى "نمره كلى انخيزش تحصيلى “ كه از ميانگين كل گويههاى

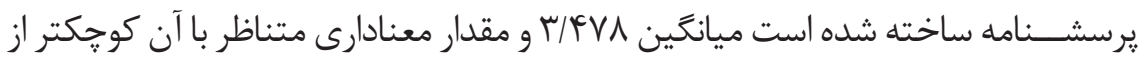

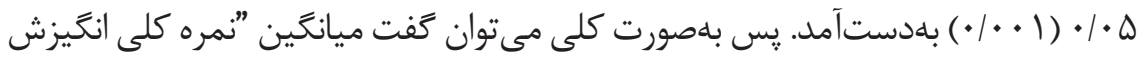
تحصيلى "در حد مطلوب اســت. با توجه به ميانگين حاصل، نمره كلى انخيزش تحصيلى كمتر از ץ انخيزش كمه نمره بين r تا F انخيزش متوسط و نمره بيشتر از \& انخيزش زياد قرار گرفتند و درصد آزمودنىهاى هر كدام از اين طبقات مشخص شد (جدول ؟). جدول r. دستهبندى آزمودنىها بر اساس نمره كلى انگيزش تحصيلى

\begin{tabular}{|c|c|c|c|c|}
\hline درصد تجمعى & درصد & فراوانى & & ن نام متغي \\
\hline $9 / \Delta$ & $9 / 0$ & 9 & كم & \multirow{3}{*}{ انغيزش تحصيلى } \\
\hline $9 \Delta$ & $\wedge \Lambda / \Delta$ & Irr & متوسط & \\
\hline $1 .$. & $\Delta$ & $v$ & زياد & \\
\hline
\end{tabular}

بر اســاس مندرجات جدول rاز كل شركت كنيندگان، 9 نفر معادل ه/9 درصد نمره انخيزش كم يعنى "كمتر از ب"، س ا ا نفر معادل NN/D درصد نمره انخيزش متوسط يعنى 


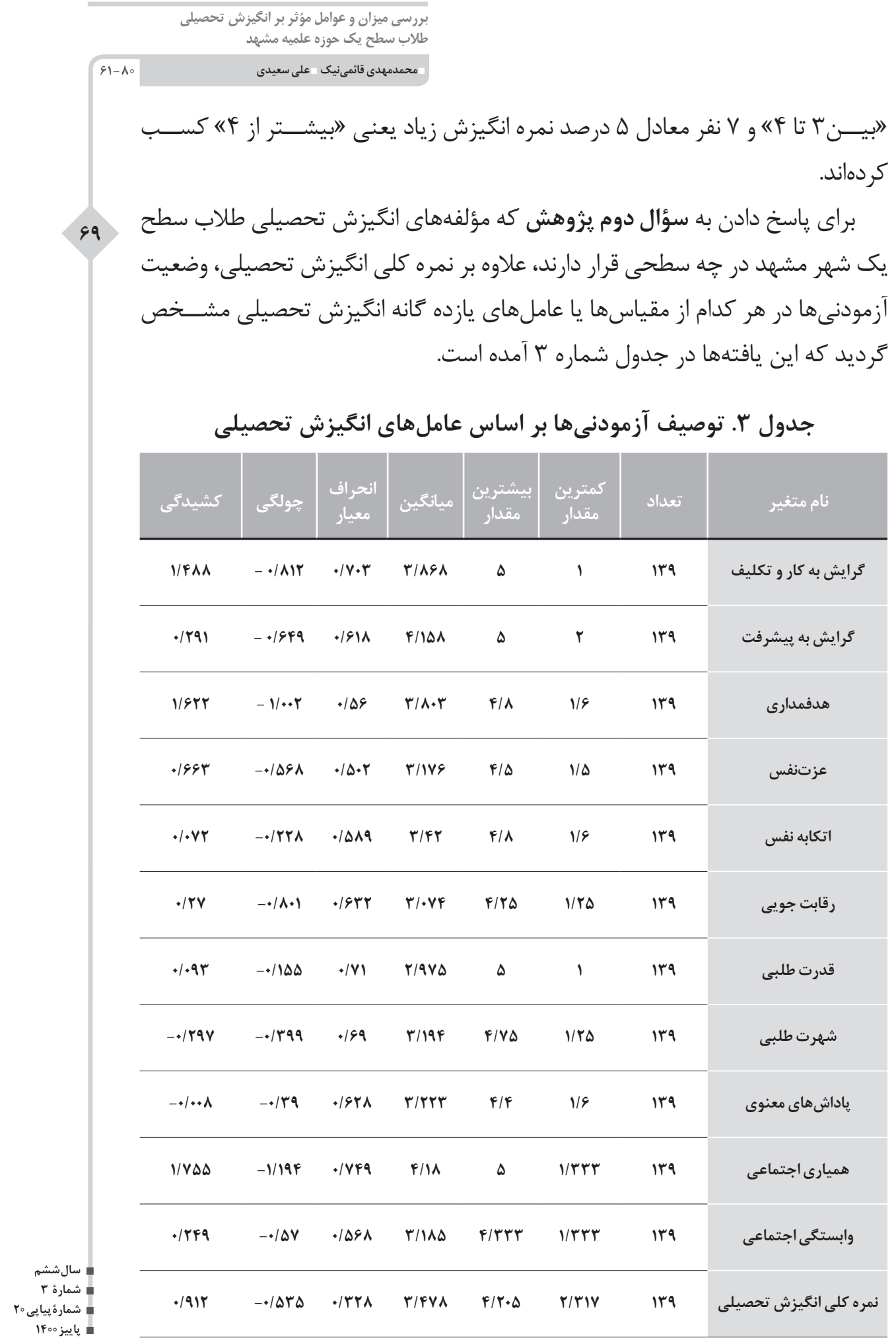




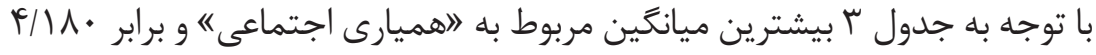

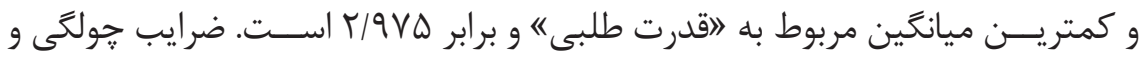
كشـــيد ضرايب جولكى و كشيدگى فرض نرمال بودن دادهها براى اين شاخصها تأييد مىشود. در اين يزوهش براى رتبهبندى شاخصهاى يرسشنامه از آزمون فريدمن استفادهده اســت. در آزمون فريدمن فرضيه صفر مبتنى بر يكســان بودن ميانگين رتبهها در بين گروههاســت. رد شدن اين فرضيه صفر به اين معنى است كه در بين گروهها حداقل دو كروه باهم اختلاف معنادارى دارند.

جدول F نتايج آزمون رتبهبندى فريدمن

\begin{tabular}{|c|c|c|c|c|}
\hline معنادارى مقدار & آماره كائ & رتبه & ريانتين & 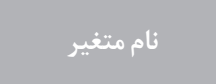 \\
\hline \multirow{11}{*}{$.1 . .1$} & \multirow{11}{*}{$\Delta|\Lambda / T H|$} & 1 & $q / 1 \Delta \wedge$ & كرايش به هيشرفت \\
\hline & & $r$ & $\wedge / 9 \vee \wedge$ & هميارى اجتماعى \\
\hline & & $r$ & $V / V V V$ & هدفمدارى \\
\hline & & $f$ & V/q9F & كرايش به كار و تكليف \\
\hline & & $\Delta$ & $\Delta / V F \Lambda$ & اتكا به نفس \\
\hline & & 9 & $F / 9 \& \wedge$ & ياداشهاى معنوى \\
\hline & & v & $F / \wedge V F$ & شهرت طلبى \\
\hline & & $\wedge$ & $F / F \Delta V$ & وابستتگى اجتماعى \\
\hline & & 9 & $F / r \wedge I$ & عزتنفس \\
\hline & & 1. & F/rAT & رقابت جويى \\
\hline & & 11 & r/AIr & قدرت طلبى \\
\hline
\end{tabular}




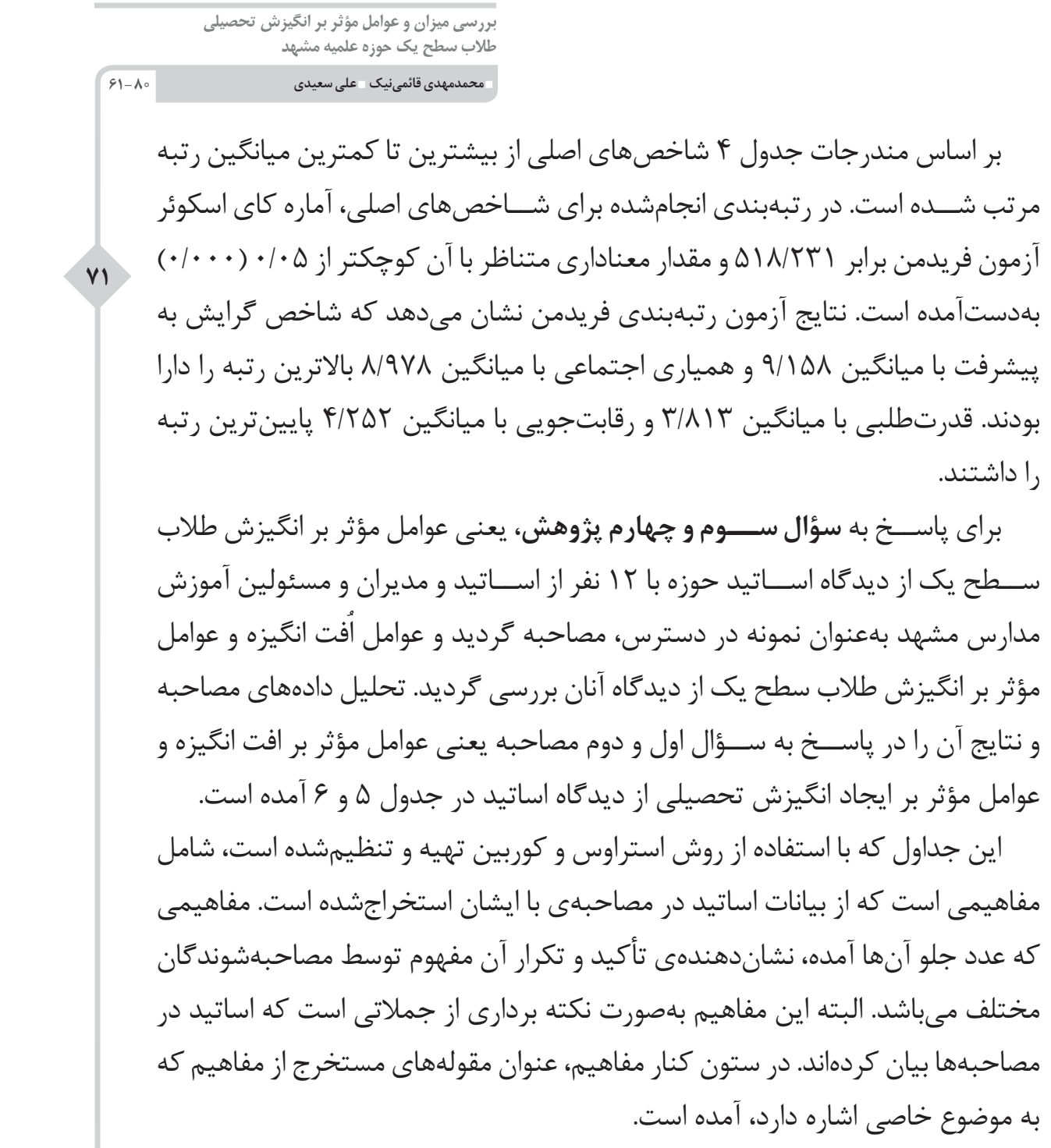


جدول ه. مفاهيم و مقوله هاى مستخرج از دادههاى كيفى

در مورد عوامل افت انظيزه از ديدكاه اساتيد حوزه مونه

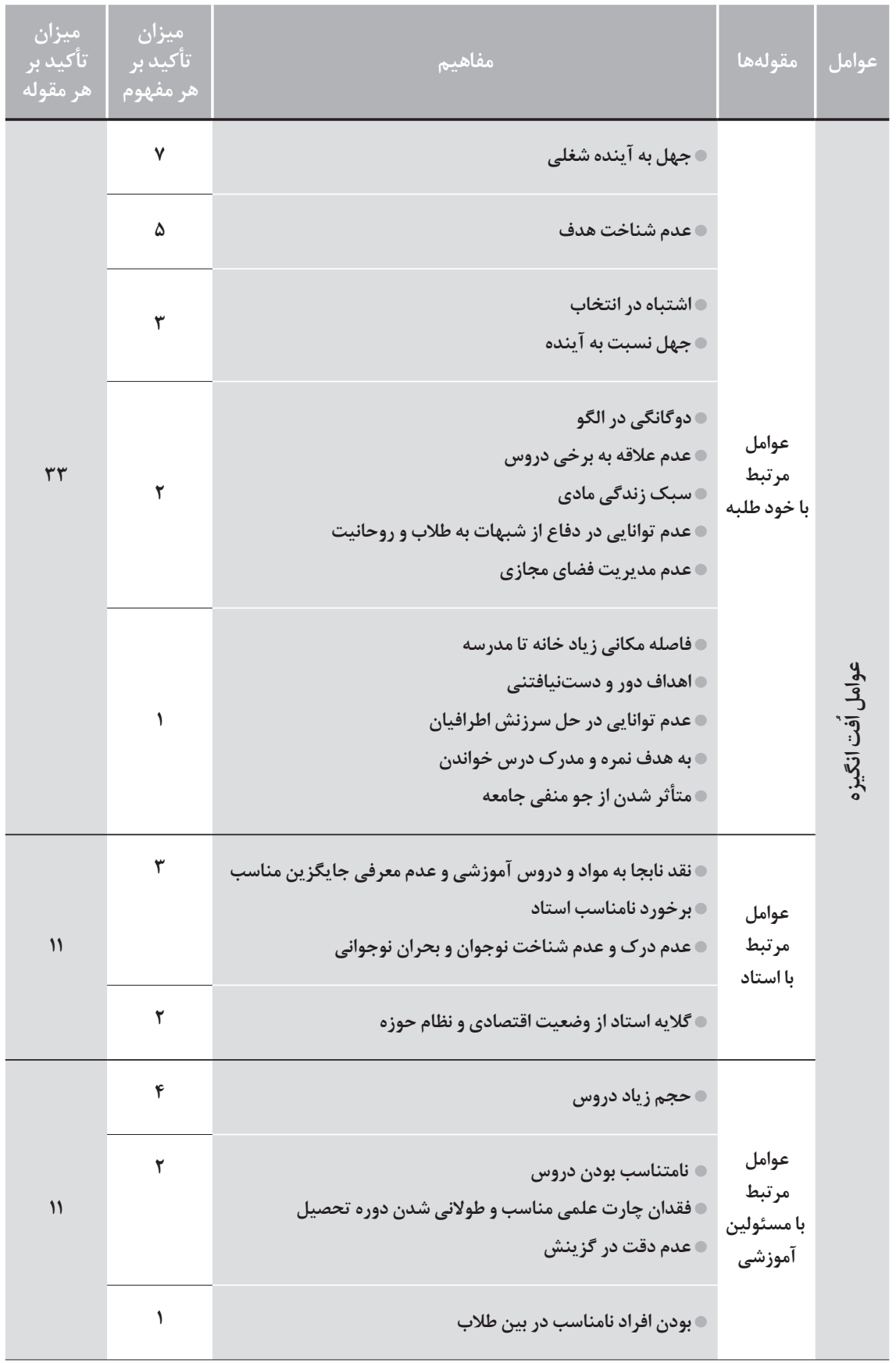




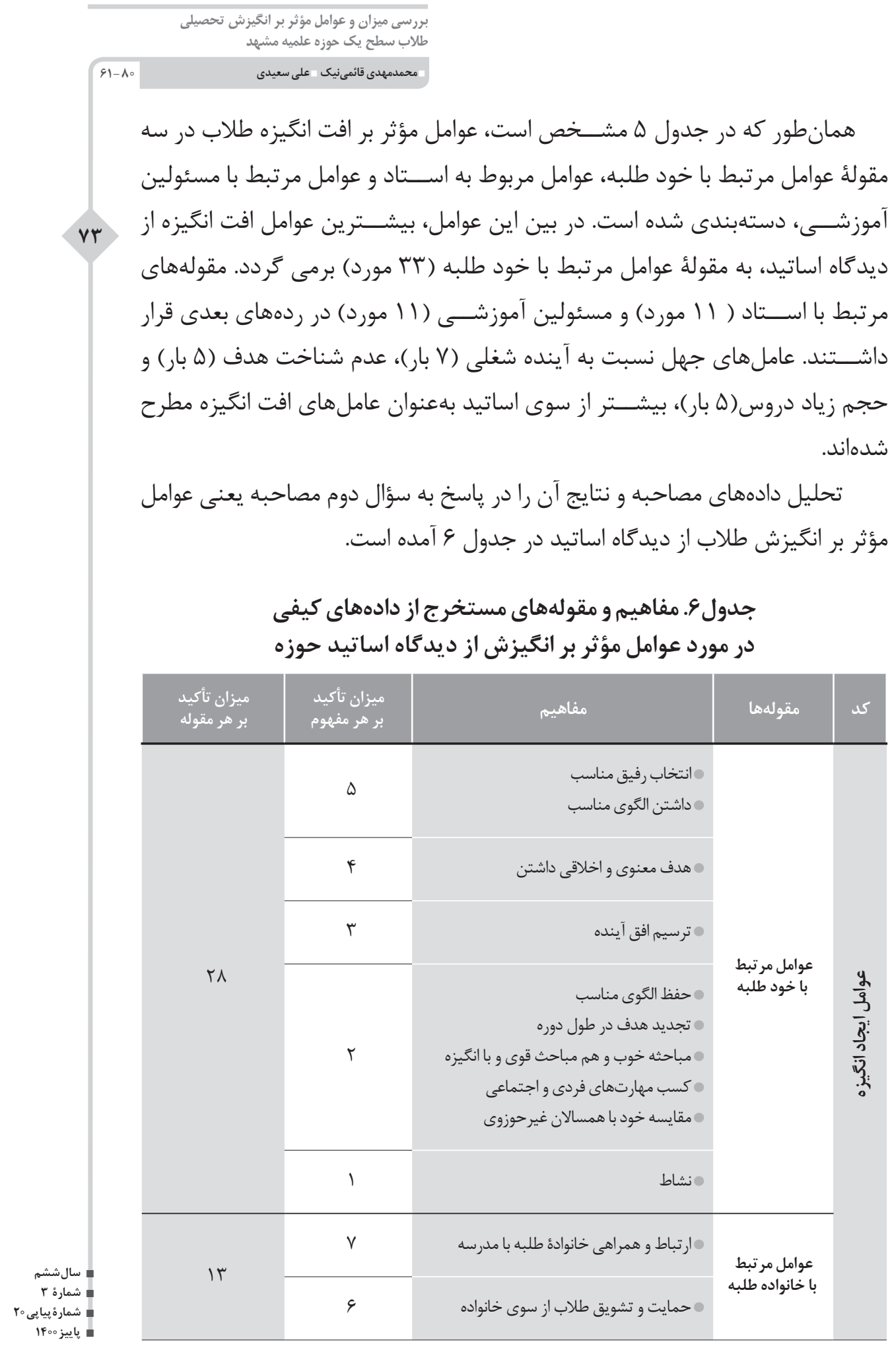




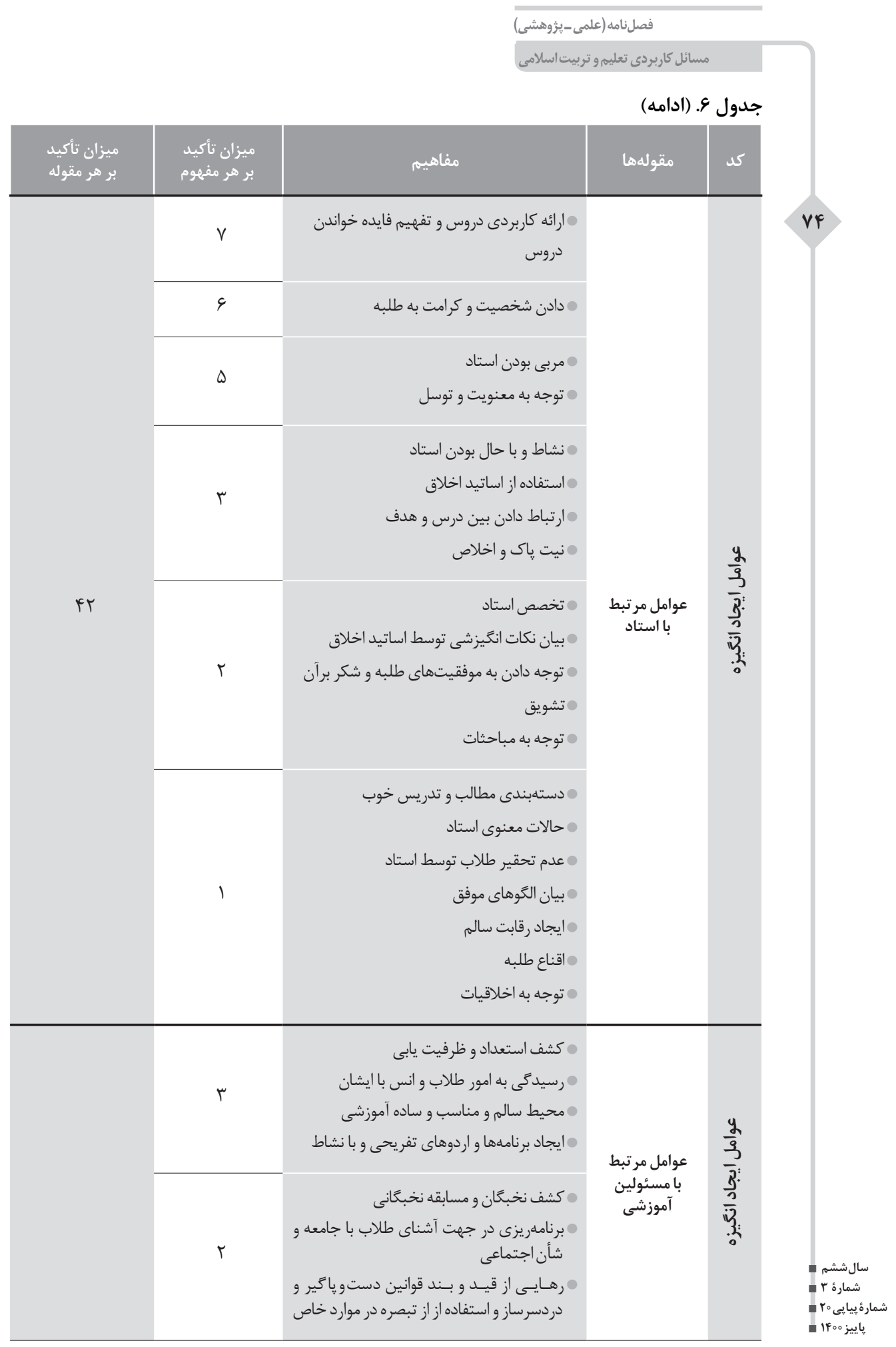




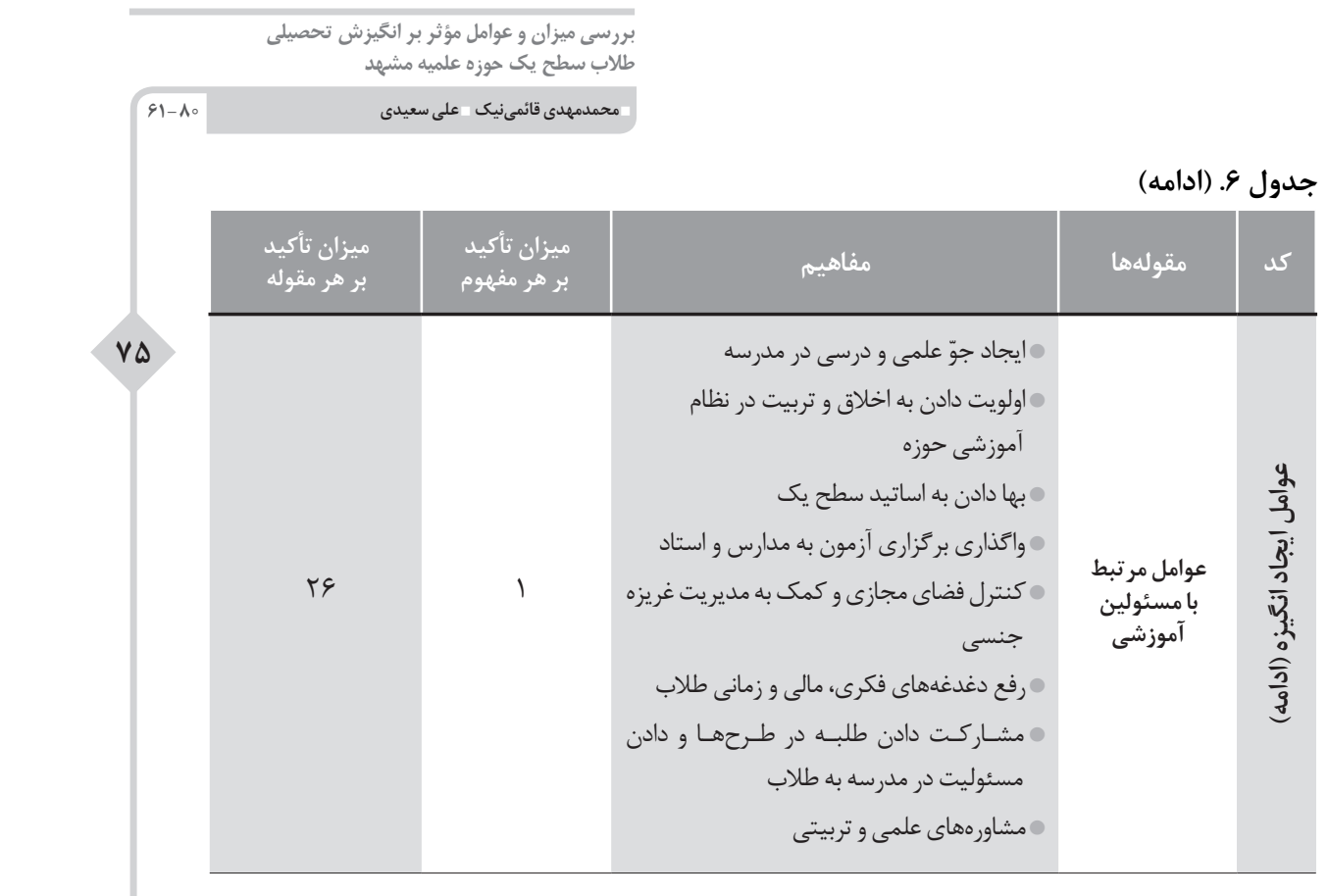

همانطور كه در جدول 9 مشخص است، عوامل مؤثر بر انگَيزش تحصيلى طلاب در

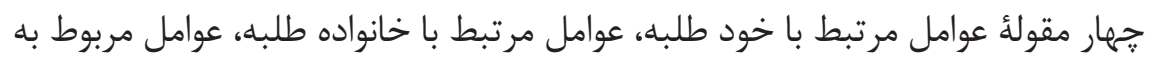

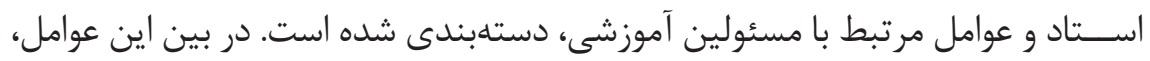

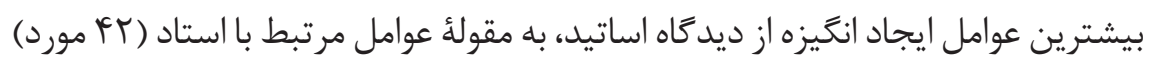

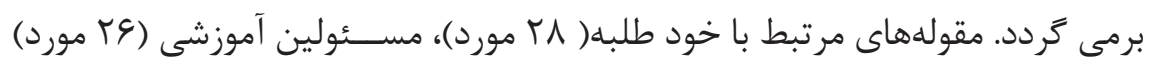

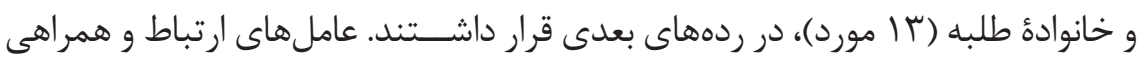

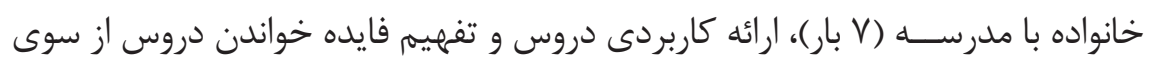

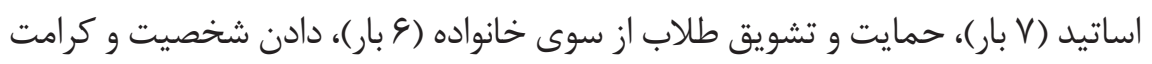

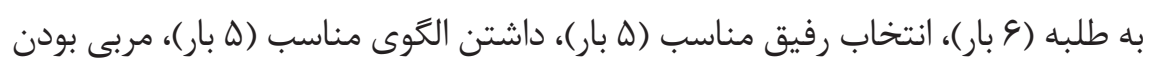

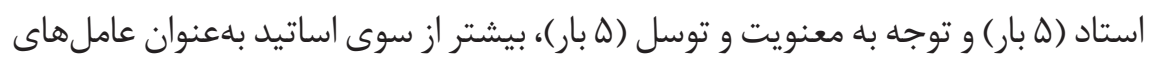
ايجاد انكَيزه مطرح شدهاند.

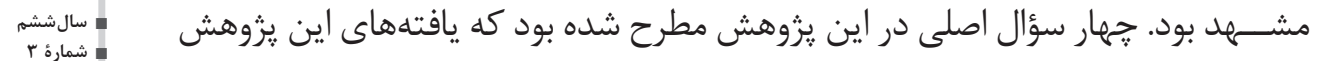

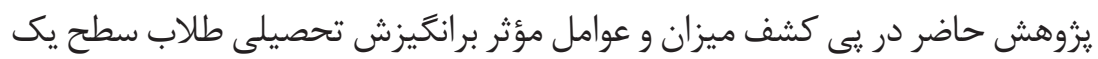




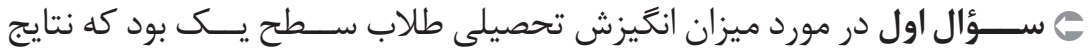

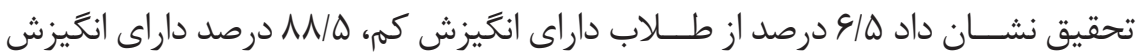

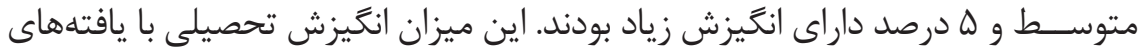

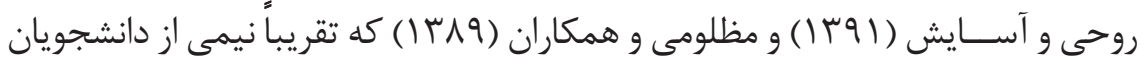

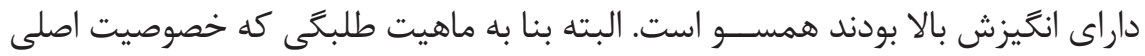

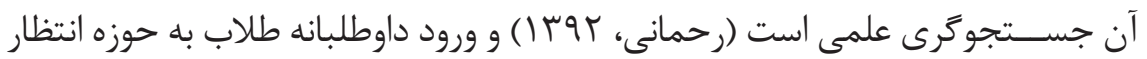

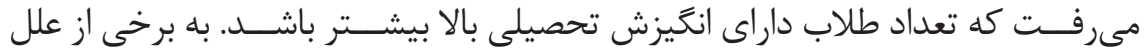

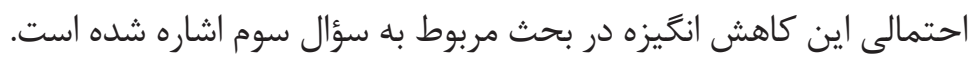

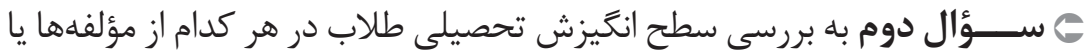

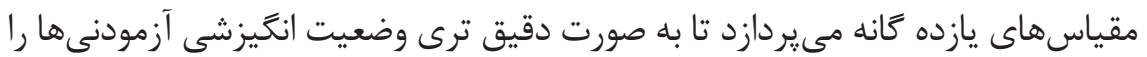
نشان دهد. يافتههاى يزوهش نشان داد كه از بين مؤلفههاى انخَيزش تحصيلى، ميانكَين

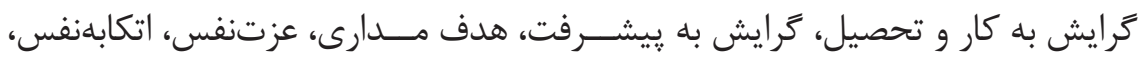

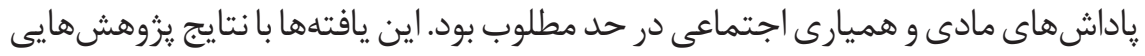

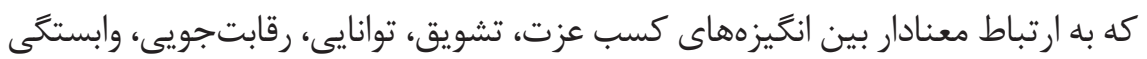

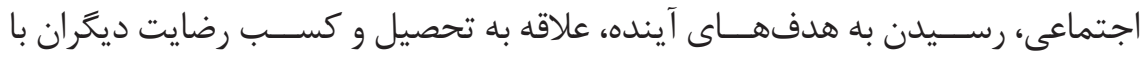

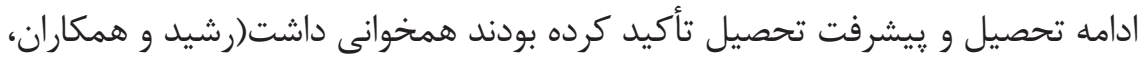

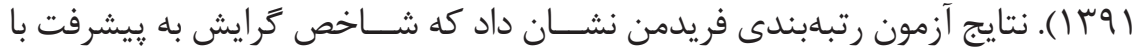

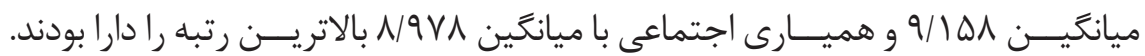

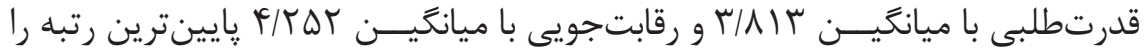

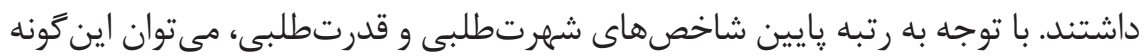

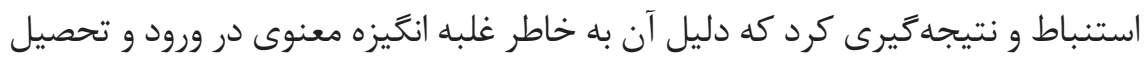

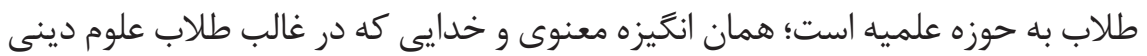

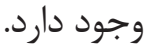

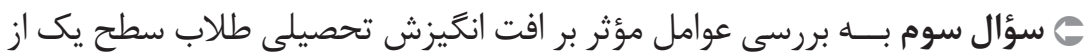

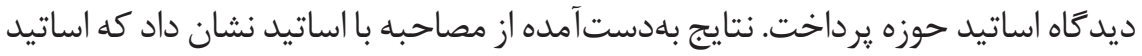

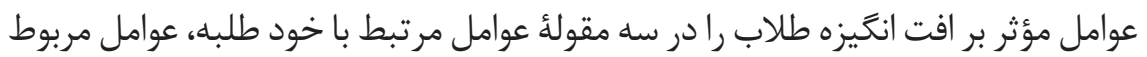
به اســاد و عوامل مرتبط با مسئولين آموزشــى مى دانند. در بين اين عوامل، بيشترين

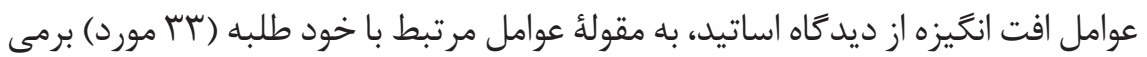




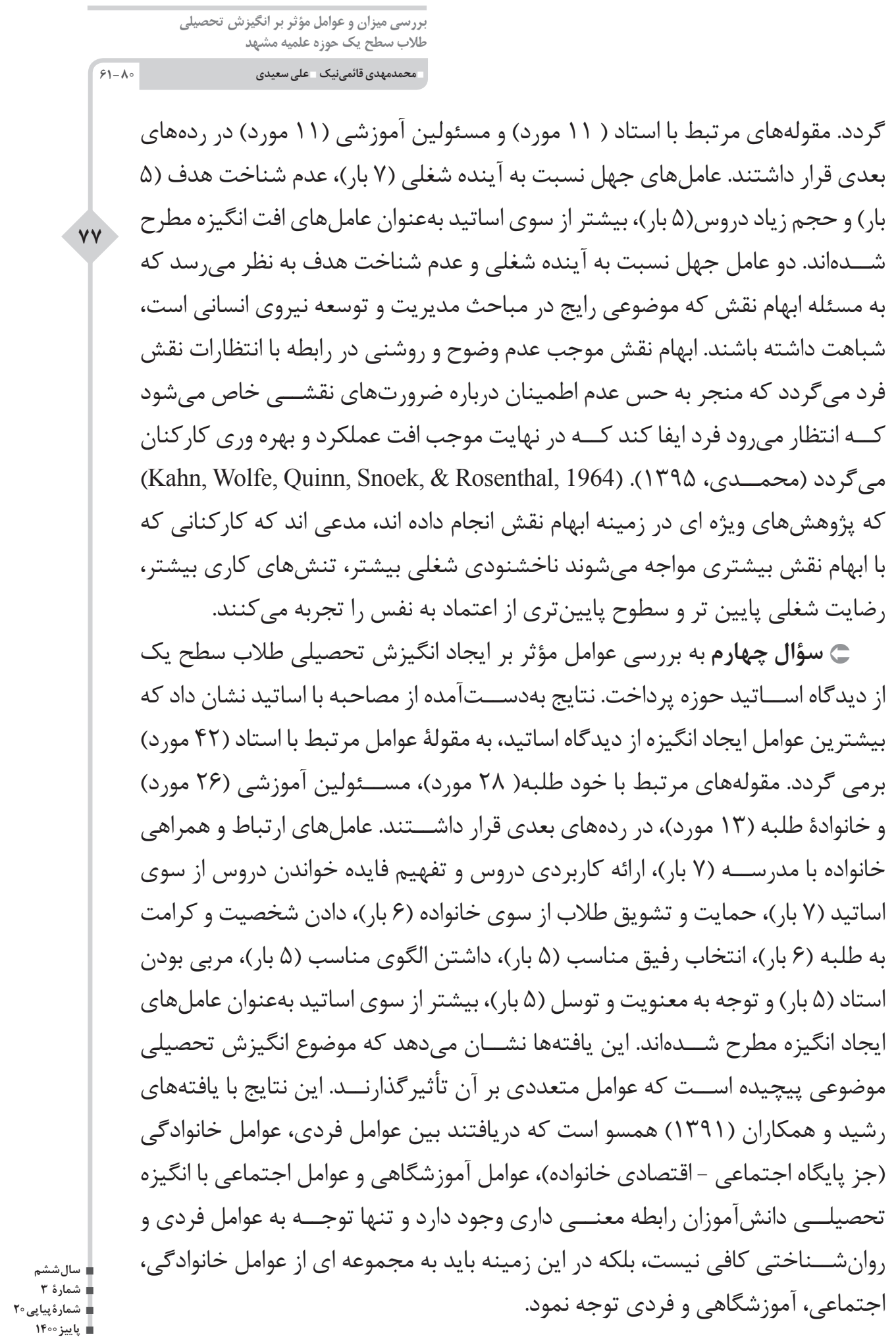


نظر اغلب اساتيد بهعنوان كسانى كه بهطور مستقيم در آموزش طلاب درگيرند نشان

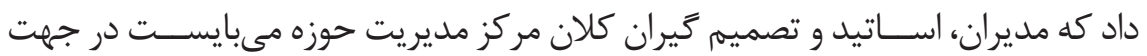
روشنگرى و تبيين طلاب نسبت به اهداف حوزوى و ارائه الكويى مناسب، تلاش كنند. نكته ديخر اينكه حجم دروس سطح يك مىبايست مورد بازبينى و اصلاح قرار زيرد زيرا فراوانى حجم دروس خصوصاً در يايههاى اوليه سطح يك و همجنين نامتناسب بودن برخى مواد درسى، در كاهش انخيزه طلاب مؤثر است. اين نتيجه با يافتههاى يزوهش مهريه (بوس |) همسويى دارد. عواملى جون تشــويق و به كاركيرى برنامههاى تقويت، جوّ مثبت كلاس، استفاده از روشهاى مشار كتى بهجاى روش هاى سخنرانى و توجه به نيازهاى عاطفى طلاب نيز از عوامل مؤثر بر رشد و ارتقاى انخيزش تحصيلى آنها محسوب مىشود. درحالى كه اين كار شروع خوبى براى كسب بينش بيشتر در مورد وضعيت انخيزشى روسى طلاب ســطح يك شهر مشهد بود، جهتخيرى هاى يثوهشــى براى آينده وجود دارد كه مى تواند فايده فورى داشته باشد. اول از همه، اين كار بايد گسترش يابد تا تعداد بيشترى از طلاب مناطق مختلف كشـــور در نمونه آمارى حضور داشته باشند. دوم، نمونهها بايد از نظر نزادى، قومى و اجتماعى و اقتصادى ناهمخًن و متنوع باشـــند. سرانجام، مصاحبه با حداقل برخى از طلاب باويزه طلاب داراى انگيزش بالا و وايين، براى بررسى نظر آنها

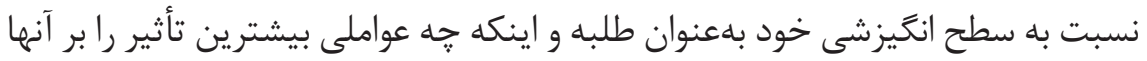
داشته است، بسيار ارزشمند خواهد بود. بهطور ويزه يِيشنهاد مى گردد با توجه به نخرش و گرايش به تحصيل در شهر قم، اين موضوع در اين شهر هم مورد بررسى قرار گرفته و ميزان انخيزش طلاب اين دو شهر را با يكديگر مقايسه كنند. همجنين تحقيقى بر روى

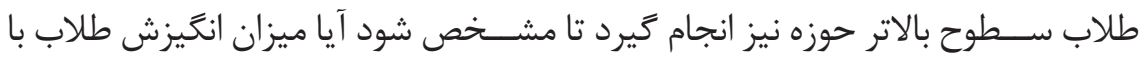
افزايش سنوات تحصيلى، كاهش يا افزايش بيدا مى كند.

\section{تُشَّر و قدردانى}

در يايان از همكارى و عنايت تمامى طلاب، اساتيد و مديران مدارس علميه

فاضليه، ثقلين، كلبهار، سيادت و موسوى نزاد مشهد كه در اين يزوهش مشاركت نمودند و تجربيات و يافتههايشان را در اختيار محققين قرار دادند،

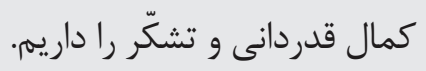




\section{منابع}

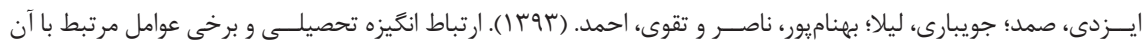

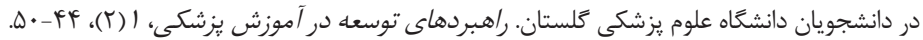

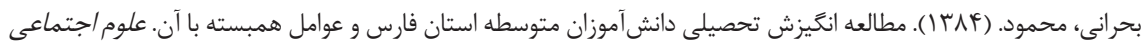

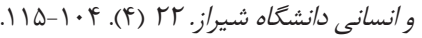

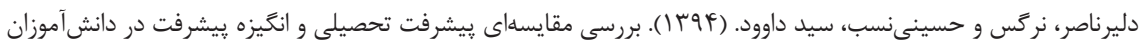

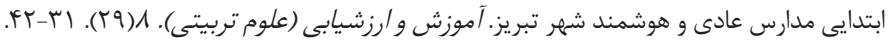

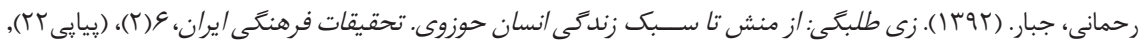
F

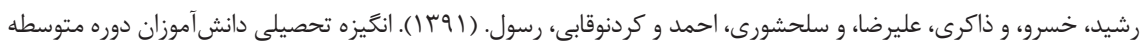
در رابطه با عوامل محيطى. فناورى آموزش (فناورى و آموزش). V) V(r). رمضانى، خسرو. (ع (1) ). روانشناسى تربيتى و كاربردهاى آن. ياسوج: فاطميه.

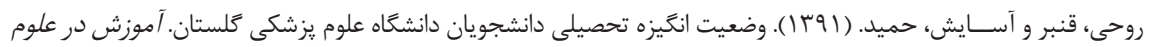

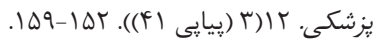

سيف، على اكبر. (99 (1). روانشناسى يرورشى نوين: روانشناسى يادكيرى و آموزش. تهران: دوران

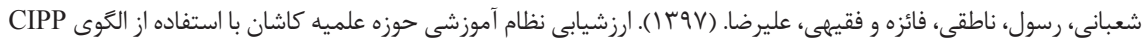

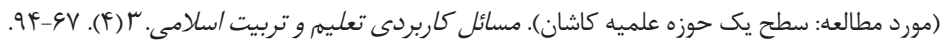

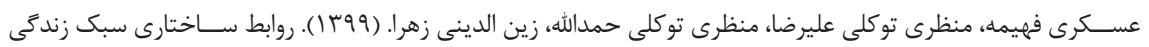

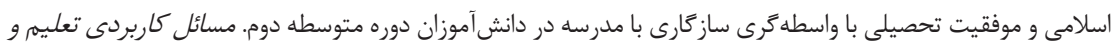

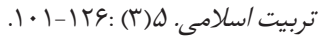

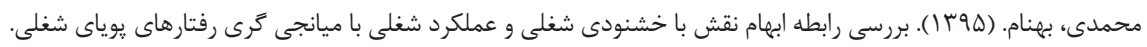

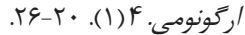

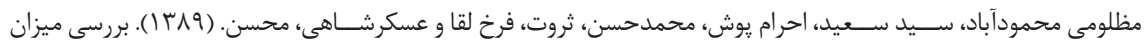

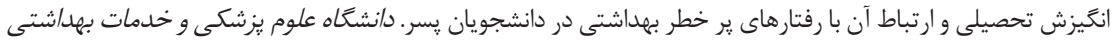

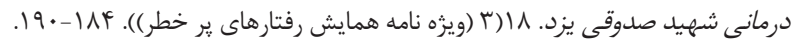
موحد ابطحى، حجت. (لهوب (). آشنايى با حوزههاى علميه شيعه در طول تاريخ. اصفهان: حوزه علميه اصفهان.

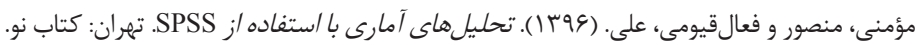

مهديه، حميد. (باوس (). بررسـى رابطه ميان انكيزش و ييشرفت تحصيلى در دو گروه از طلاب ورودى سيكل و دوره متوسطه.

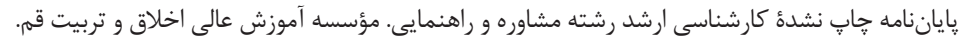

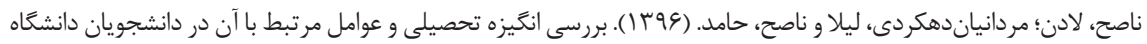

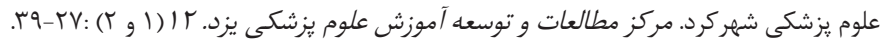

\section{REFERENCES}

Brian P.An (2015) The Role of Academic Motivation and Engagement on the Relationship between Dual Enrollment and Academic Performance, The Journal of Higher Education, 86:1, 98-126.

vq Clark, M. H., Middleton, S. C., Nguyen, D., \& Zwick, L. K. (2014). Mediating relationships between academic motivation, academic integration and academic performance. Learning and individual differences, 33, 30-38. 
Rowell, L., Hong, E. (2013). Academic motivation: Concepts, strategies, and counseling approaches. Professional School Counseling, 16(3), 158-171. American School Counselor Association.

Schunk, D. H., Meece, J. R., \& Pintrich, P. R. (2012). Motivation in education: Theory, research, and applications. Pearson Higher Ed.

Steinmayr, R., \& Spinath, B. (2009). The importance of motivation as a predictor of school achievement. Learning and Individual Differences, 19, 80-90. doi:10.1016/j.lindif.2008.05.004

Zaccoletti, S., Camacho, A., Correia, N., Aguiar, C., Mason, L. \& Daniel, J. R. (2020). Parents' Perceptions of Student Academic Motivation During the COVID-19 Lockdown: A Cross-Country Comparison. Frontiers in psychology, 11, 592670. https://doi.org/10.3389/ fpsyg.2020.592670

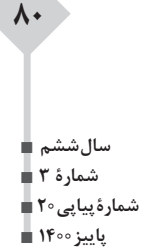

